Editors' Note: In WriteClick this week, Mr. Zahednasab argues that the status of the disease of a patient with multiple sclerosis (MS) is relevant when discussing viruses and MS. He supports his claim, as is customary in scholarly writing, with a reference. The authors respond simply that the referenced study "has been challenged," a statement that this editor plans on appropriating for frequent use in the future. The authors similarly defend their opposition with a reference. Two dueling studies with equal methods, published in the same journal, produce contradictory results on their way to polar opposite conclusions.

Megan Alcauskas, MD, and Robert C. Griggs, MD

\section{NEUROLOGIC DISABILITY: A HIDDEN EPIDEMIC FOR INDIA}

Nitin K. Sethi, New York: Das et al. ${ }^{1}$ examined the epidemic of neurologic disability in India. As the authors noted, it is not just hidden but ignored. In large metropolitan areas such as New Delhi and Mumbai, excellent health care facilities currently exist for the treatment of acute stroke, traumatic brain injuries (TBI), and neurodegenerative conditions such as dementia. Patients from neighboring cities and villages flock to these centers to receive care. The time period after patients leave the hospital is the problem that is ignored by the government and medical community. In the absence of comprehensive TBI and stroke rehabilitation centers, patients are discharged and the burden of care falls on family and close friends. With few patients receiving comprehensive speech, physical, and occupational therapy, neurologic outcomes are poor, which adds to disease burden. In countries like India where resources are limited and demands high, neurologic disability from TBI and stroke can only be reduced if the emphasis is on prevention by modification of respective risk factors. This should be reflected in the national health policies of these countries, with adequate allocation of resources toward primary prevention of TBI and stroke as well as establishment of nursing homes and other subacute facilities to take care of these patients after discharge.

\section{(C) 2013 American Academy of Neurology}

1. Das A, Botticello AL, Wylie GR, Radhakrishnan K. Neurologic disability: a hidden epidemic for India. Neurology 2012;79:2146-2147.
Mamta Bhushan Singh, New Delhi: I read the article by Das et al. ${ }^{1}$ with interest. Das et al. ${ }^{1}$ correctly identify TBI, dementia, and stroke as contributors to the epidemic of neurologic disability. Epilepsy should also be included. Epidemiologic studies have suggested that there are 10-12 million Indians with epilepsy and approximately $73 \%-78 \%$ are not receiving appropriate treatment. ${ }^{2}$ Within India, the treatment gap varies widely between the rural and urban regions and a treatment gap of up to $90 \%$ has been reported for rural populations. ${ }^{3}$ Disability in epilepsy remains largely hidden. The connection with disability in the context of epilepsy is rarely discussed. When it is mentioned, intellectual disability is often the focus. Untreated or inadequately treated epilepsy commonly leads to other forms of disability: loss of an eye, limb, teeth, or digit, or burn-related injury. It is vital to include epilepsy when calculating neurologic disability because it is preventable in those who are treatment naive as they respond well to antiepileptic drugs. Mandatory inclusion of "Axis 5" from the 2001 ILAE report ${ }^{3}$ in the diagnosis of all patients with epilepsy may be a beginning.

\section{(C) 2013 American Academy of Neurology}

1. Das A, Botticello AL, Wylie GR, Radhakrishnan K. Neurologic disability: a hidden epidemic for India. Neurology 2012;79: 2146-2147.

2. Ray B, Bhattacharya S, Kundu T, Saha S, Das S. Epidemiology of epilepsy: Indian perspective. J Indian Med Assoc 2002;100: 322-326.

3. Meyer AC, Dua T, Ma J, Saxena S, Birbeck G. Global disparities in the epilepsy treatment gap: a systematic review. Bull World Health Organ 2010;88:260-266.

4. Jerome E Jr. A proposed diagnostic scheme for people with epileptic seizures: report of the ILAE Task Force on classification and terminology epilepsia. ILAE Commission Report 2001;42:796-803.

\section{IMPAIRMENT OF JCV-SPECIFIC T-CELL RESPONSE BY CORTICOTHERAPY: EFFECT ON PML-IRIS MANAGEMENT?}

Hamid Zahednasab, Tehr, Iran: Antoniol et al. described the impairment of JC virus (JCV)-specific T-cell response by corticosteroid therapy. The authors did not indicate if patients with relapsing-remitting multiple sclerosis (RRMS) were in relapse or remission stage of the disease. Sotelo et al. ${ }^{2}$ showed that the viral 


\section{Neurology}

\section{Neurologic disability: A hidden epidemic for India \\ Nitin K. Sethi and Mamta Bhushan Singh \\ Neurology 2013;81;97 \\ DOI 10.1212/WNL.0b013e31829b2523}

\section{This information is current as of July 1, 2013}

\section{Updated Information \& Services}

\section{References}

Citations

Permissions \& Licensing

Reprints including high resolution figures, can be found at: http://n.neurology.org/content/81/1/97.1.full

This article cites 5 articles, 2 of which you can access for free at: http://n.neurology.org/content/81/1/97.1.full\#ref-list-1

This article has been cited by 1 HighWire-hosted articles: http://n.neurology.org/content/81/1/97.1.full\#\#otherarticles

Information about reproducing this article in parts (figures,tables) or in its entirety can be found online at:

http://www.neurology.org/about/about_the_journal\#permissions

Information about ordering reprints can be found online:

http://n.neurology.org/subscribers/advertise

Neurology ${ }^{\circledR}$ is the official journal of the American Academy of Neurology. Published continuously since 1951, it is now a weekly with 48 issues per year. Copyright (C 2013 American Academy of Neurology. All rights reserved. Print ISSN: 0028-3878. Online ISSN: 1526-632X.

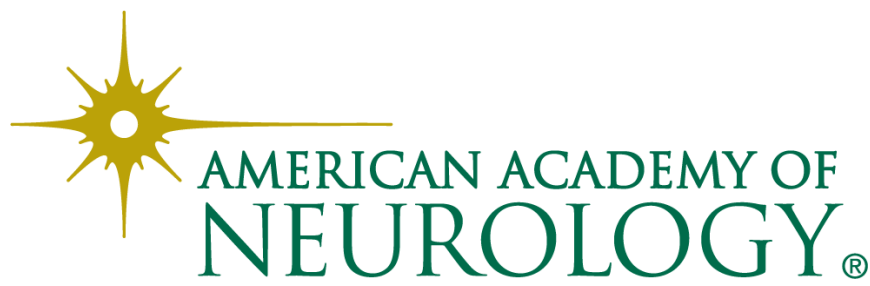

